\title{
Cost-Effective Thin n-type Silicon Solar Cells with Rear Emitter
}

\author{
Adriano Moehlecke ${ }^{a *}$ (D), Tatiana Lisboa Marcondes ${ }^{a}$, Jéssica de Aquino ${ }^{\text {, Izete Zanesco }}{ }^{a}$, Moussa Ly \\ a Pontifícia Universidade Católica do Rio Grande do Sul, Escola Politécnica, Núcleo de Tecnologia em \\ Energia Solar, Av. Ipiranga, 6681, P.96A, 90619-900, Porto Alegre, RS, Brasil.
}

Received: September 23, 2019; Revised: January 13, 2020; Accepted: January 29, 2020

\begin{abstract}
The silicon solar cells achieved relatively low prices in the last years and to introduce a new structure in the PV industry, the amount of silicon per watt has to be reduced, requiring a cost-effective manufacturing process. The use of n-type solar grade silicon has the advantages of presenting higher minority carrier lifetime than p-type one and the absence of the boron-oxygen defects. The aim of this paper is to present the development of $100 \mu \mathrm{m}$ thick $\mathrm{n}^{+} \mathrm{np}^{+}$silicon solar cells with a selective $\mathrm{p}^{+}$rear emitter formed by boron deposited by spin-on and an $\mathrm{Al} / \mathrm{Ag}$ grid deposited by screen-printing. The firing temperature of $\mathrm{Ag} / \mathrm{Al}$ (rear face) e Ag (front face) was optimized and the temperature of $840{ }^{\circ} \mathrm{C}$ produced the devices with higher efficiency. The solar cells presented efficiencies of $16 \%$, achieving a low silicon consumption of $1.6 \mathrm{~g} / \mathrm{W}, 40 \%$ lower than thick p-type devices produced by the same process.
\end{abstract}

Keywords: thin Si solar cells, n-type Si, rear emitter.

\section{Introduction}

Most industrial solar cells are produced by using $180 \mu \mathrm{m}$ thick silicon wafers grown by the Czochralski (Cz) method (monocrystalline wafers) or by block-casting process (multicrystalline wafers). The $\mathrm{n}^{+} \mathrm{pp}^{+}$structure with the front phosphorus doped emitter and the $\mathrm{p}^{+}$BSF (back surface field) formed by aluminum paste and diffusion in a belt furnace has been a standard in the photovoltaic (PV) industry in the last decades. Efficiencies of $17 \%-19 \%$ are currently obtained ${ }^{1}$. The silicon wafer represents $52 \%$ of the solar cell cost and $28 \%$ of the PV module cost, as reported by the International Technology Roadmap for Photovoltaic ${ }^{2}$. Thinner wafers can be used to reduce the PV module cost and there is a perspective that in 2029 the industry will probably use $120 \mu \mathrm{m}$ wafers with $120 \mu \mathrm{m}$ kerf loss, reducing the silicon consumption by $27 \%$ if breakage will not increase and efficiency will be maintained ${ }^{2,3}$.

The $\mathrm{n}^{+} \mathrm{pp}^{+}$structure based on screen-printed Al layer cannot be applied to the thin wafers bearing in mind the wafer bowing ${ }^{4}$. The bow is produced during the thermal step performed to diffuse $\mathrm{Al}$ into a silicon in a belt furnace due to the different thermal coefficients of expansion of aluminum layer and silicon. The wafer bowing can lead to cracking during soldering and lamination processes to assemble the PV modules.

Although the p-type silicon is used to manufacture solar cells, it is susceptible to light-induced degradation (LID) due to boron-oxygen interaction ${ }^{5-8}$. The open circuit voltage of p-type devices can decrease in order of 3\%-4\% in the first hours of solar radiation exposure due to the reduction of minority carrier lifetime 5 . On the other hand, the devices processed in n-type $\mathrm{Si}$, doped with phosphorus, did not present such degradation. Glunz ${ }^{\mathrm{a}}$ et al. reported that the minority carrier lifetime reduction was also observed in p-type cells

*e-mail: moehleck@pucrs.br kept under reverse bias voltage ${ }^{5}$. Therefore, performance degradation of p-type devices is caused by the injection of excess minority carriers produced by photons or by reverse bias and the interaction of the carriers with B-O complexes ${ }^{5,6}$.

Besides the absence of LID, the efficiency of n-type devices are less affected by metallic contaminants common in silicon solar cell production ${ }^{9,10}$. For instance, the interstitial $\mathrm{Fe}$ is more effective in capturing electrons than holes due to the positive charge state. Since electrons are the minority carriers in p-type wafers, this metallic impurity causes a lower minority carrier lifetime in p-type than n-type silicon ${ }^{10}$.

In the last years, review papers on n-type silicon solar cells were published pointing out the advantages of these devices and the difficulties concerning the industrial production ${ }^{11-14}$. The structures developed in n-type silicon can be categorized as: 1) front-emitter solar cell $\left(\mathrm{p}^{+} \mathrm{n}\right.$ ou $\left.\mathrm{p}^{+} \mathrm{nn}^{+}\right)$such as passivated emitter and rear cell (PERC), passivated emitter rear totally diffused (PERT), passivated emitter rear locally diffused (PERL), emitter wrap-through and metal wrap-through (MWT); 2) back junction with front surface field (FSF), with aluminum or boron doped emitter and interdigitated back contact (IBC) cells; 3) hetero-junction with intrinsic thin layer (HIT) solar cells and 4) ion implanted devices (generally with rear emitters). With the exception of HIT structure, high efficiency solar cells are produced with boron doped emitters obtained by diffusion with $\mathrm{BBr}_{3}$ as source or by ion implantation. The former boron source remains as a standard to produce solar cells, even though the boron rich layer (BRL) formed during the thermal process can hinder surface passivation and can degrade the minority carrier lifetime ${ }^{15}$.

The IBC and HIT are high efficiency solar cells fabricated in n-type wafers, achieving the efficiency of $25 \%$, but high quality surface passivation and high quality wafers are needed $^{12,14,16}$. 
Efficiencies near $22 \%$ were reported for $\mathrm{p}^{+} \mathrm{nn}^{+}$PERT solar cell ${ }^{17}$. In this solar cell, boron and phosphorus diffusions were carried out by using $\mathrm{BBr}_{3}$ and $\mathrm{POCl}_{3}$, oxide growth steps were implemented and $\mathrm{SiO}_{2}$ layer passivated the rear face and $\mathrm{Al}_{2} \mathrm{O}_{3} / \mathrm{SiN}_{\mathrm{x}}$ passivated the front face. An aluminum layer $(2 \mu \mathrm{m}$ thick) was deposited by e-beam evaporation on the whole rear face, contacting the rear face by holes in the $\mathrm{SiO}_{2}$ layer. The front metal grid was deposited by electroplating of $\mathrm{Cu} / \mathrm{Ni} / \mathrm{Ag}$. Otherwise, Lu et al. ${ }^{18}$ presented a $\mathrm{p}^{+} \mathrm{nn}{ }^{+}$cell without an Al layer deposited on the rear face, achieving an efficiency of around $21 \%$. The rear face was passivated by $\mathrm{SiO}_{2}$ thermally grown layer and on the front face was deposited the $\mathrm{SiO}_{2} / \mathrm{Al}_{2} \mathrm{O}_{3} / \mathrm{SiN}_{\mathrm{x}}$ stack layer. The $\mathrm{n}^{+}$region was obtained by ion implantation and $\mathrm{p}^{+}$was produced by boron diffusion with $\mathrm{BBr}_{3}$ as source. Rear emitter solar cells were developed by using $\mathrm{BBr}_{3}$ as a boron source and $\mathrm{Cz}$ and epitaxially (epi) grown n-type wafers. The efficiencies near to $22 \%$ were reached ${ }^{13}$.

In order to substitute the $\mathrm{BBr}_{3}$ as boron source, Rhotard et al. ${ }^{19}$ deposited a borosilicate layer by atmospheric pressure chemical vapor deposition (APCVD) and performed a B/P co-diffusion during the thermal step. They reported a dark saturation current density of $80 \mathrm{fA} / \mathrm{cm}^{2}$, allowing for an implied open circuit voltage of $650 \mathrm{mV}$. By using plasma enhanced chemical vapor technique to deposit a borosilicate layer, Wehmeier et al. ${ }^{20}$ produced n-type PERT cells with rear junction $\left(n^{+} n p^{+}\right)$that reached the efficiency of $20.7 \%$. Spin-on dopants have also been used as source to form the heavily doped regions in diffusion thermal steps ${ }^{21-23}$. Boric acid was used as a boron dopant by Das et al. ${ }^{22}$ to produce n-type back junction solar cells, achieving efficiencies over $20 \%$ in $4 \mathrm{~cm}^{2}$ devices passivated with $\mathrm{SiO}_{2}-\mathrm{SiN}_{\mathrm{x}}$ stack. A comparison of n-type PERT solar cells $\left(\mathrm{p}^{+} \mathrm{nn}^{+}\right)$with boron emitter formed by spin-on coating (boric acid), screen-printing of boron paste, ion implantation, and APCVD was presented by Ryu et al. ${ }^{23}$. The authors showed that different B emitter technologies can produce devices with efficiencies nearly of $20 \%{ }^{23}$.

Concerning thin n-type Si wafers, the heterojunction solar cells were studied by using commercial $200 \mu \mathrm{m}$-thick $\mathrm{Cz}$ wafers thinned until to achieve the thickness of $60 \mu \mathrm{m}^{24}$. The heterojunction was formed by the deposition of $\left(\mathrm{p}^{+}\right)$ a-Si:H and (i) a-Si:H on the front face and (i)a-Si:H and $\left(\mathrm{n}^{+}\right) \mathrm{a}-\mathrm{Si}: \mathrm{H}$ on the rear face. The front and rear contacts were established with ITO (indium tin oxide) and sputtered Ag, respectively. The main conclusion reported is concerning that thin cells presented higher efficiency than thick cells when lower quality $\mathrm{Cz}$ silicon are used and simulations indicated the $24 \%$ efficient solar cells are achievable ${ }^{24}$. Although these structures can achieve high efficiencies, several processing steps are needed and the manufacturing process may be not cost-effective. Otherwise, large area PERC devices, that is, without diffusion on the rear face and both faces passivated by $\mathrm{SiN}_{\mathrm{x}}: \mathrm{H}$, were produced using $100 \mu \mathrm{m}$ thick p-type Si wafers and reached the efficiency of $16.8 \%{ }^{25}$. Thin n-type solar cells with whole rear face covered by aluminum achieved the efficiency of $18 \%$ and $19 \%$ for homogenous and selective phosphorus front surface field ${ }^{26}$. These thin devices showed a bow of $\approx 6 \mathrm{~mm}$ after metal firing and needed subsequent thermal step to reduce it.

The aim of this paper is to present the development of thin $\mathrm{n}^{+} \mathrm{np}^{+}$silicon solar cells with the $\mathrm{p}^{+}$rear emitter formed by boron deposited by spin-on and an Al/Ag grid deposited by screen-printing. Optimization of the metal pastes firing temperature was carried out and results from devices processed with $100 \mu \mathrm{m}$ are presented and compared to $\mathrm{n}^{+} \mathrm{pp}^{+}$thick solar cells. The novelty of this paper is to combine a boron emitter obtained by commercial boron spin-on dopant and thin silicon wafers to produce $n^{+} n p^{+}$solar cells, reaching similar efficiencies than those obtained by thick p-type devices processed with the same fabrication sequence.

\section{Materials and Methods}

Solar grade silicon wafers grown by the $\mathrm{Cz}$ method, n-type, phosphorus doped, resistivity of 1-20 $\Omega . \mathrm{cm}$, doping concentration ranging from $2.2 \times 10^{14}$ to $5.0 \times 10^{15} \mathrm{~cm}^{-3}$, $<100>$ orientation were used. The thickness of the wafers was reduced to approximately $100 \mu \mathrm{m}$ by a chemical etch based on $\mathrm{KOH}$ and deionized water. This solution was employed because there is not availability of thin wafers in the market.

Figure 1 shows the device fabrication process flow of the $\mathrm{n}^{+} \mathrm{np}^{+}$solar cells developed. The process starts with the anisotropic etch to form micropyramids followed by the standard RCA cleaning. A solution containing boron (PBF20, Filmtronics) was spun-on on the face and the wafers were introduced in an oven for evaporation of solvents. The boron was diffused into the one face of the wafer in a quartz tube furnace at $970{ }^{\circ} \mathrm{C}$ followed by an oxide growth, process optimized in previous works ${ }^{27,28}$. The $\mathrm{SiO}_{2}$ layer was etched away from the other face and after RCA cleaning, phosphorus was diffused in a quartz tube in the range of $845^{\circ} \mathrm{C}$ to $855^{\circ} \mathrm{C}$ by using $\mathrm{POCl}_{3}$ as source in order to achieve sheet resistances $\left(\mathrm{R}_{\mathrm{SH}}\right)$ of around $50 \Omega /$ sq. This sheet resistance is suitable to establish low contact resistivity between screen-printed metal grid and the $\mathrm{n}^{+}$region of the solar cell. As reported in an earlier paper, phosphorus has to be diffused after boron to enhance the minority carrier lifetime of the silicon wafers ${ }^{29}$. For thick $n^{+} p^{+}$devices, the

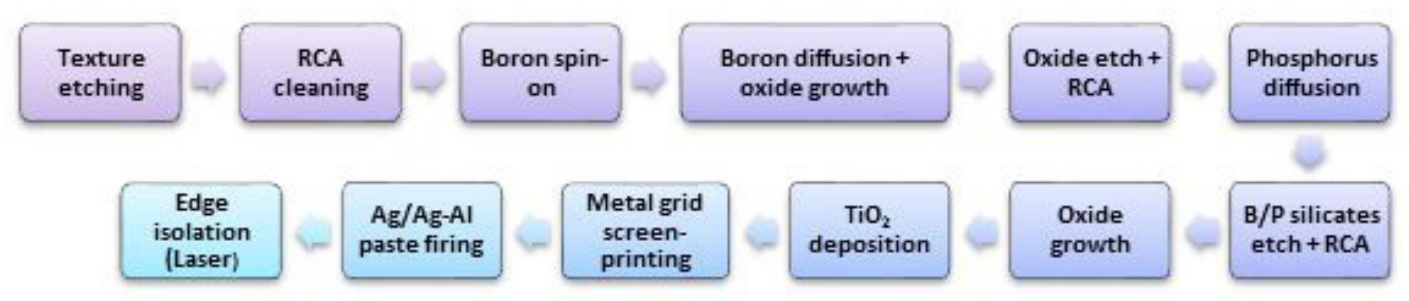

Figure 1. Fabrication process sequence used to produce thin $\mathrm{n}^{+} n \mathrm{p}^{+}$silicon solar cells. 
temperature of $845^{\circ} \mathrm{C}$ produced the devices with higher efficiency, but we increased the phosphorus diffusion temperature in this work in order to enhance the gettering mechanism in thin devices, keeping similar sheet resistances for $\mathrm{n}^{+}$regions. After that, phosphorus/boron silicate glasses (PSG and BSG) were etched by means of a hydrofluoric acid solution. The boron and phosphorus doped regions were characterized measuring the sheet resistance with the four-point probe technique and the impurity profile with the ECV (electrochemical capacitance-voltage profiling) method $^{30}$. The $\mathrm{R}_{\mathrm{SH}}$ was measured in 13 regions in the doped wafer. The thickness of the $\mathrm{n}^{+}$region and $\mathrm{p}^{+}$one as well as the surface impurity concentration $\left(\mathrm{C}_{\mathrm{S}}\right)$ were obtained from the impurity profile.

To passivate the surfaces, a thin $\mathrm{SiO}_{2}$ layer was thermally grown at $800{ }^{\circ} \mathrm{C}^{31}$ and the $\mathrm{TiO}_{2}$ antireflection coating (ARC) was deposited on the front face. The rear metal grid based on Al/Ag paste (Solamet PV3N1, from DuPont) was screen-printed and this grid has the double function: to contact the silicon wafer and produce the selective BSF region. In the non-metal covered regions on the rear face, the BSF effect is produced by boron doped region previously diffused.

On the front face, Ag grid was screen-printed (Solamet PV17A, DuPont). The pastes were dried in a belt furnace and were fired in the temperature range of $820^{\circ} \mathrm{C}-890^{\circ} \mathrm{C}$. The optimum firing temperature is of around $860^{\circ} \mathrm{C}$ to process $\mathrm{n}^{+} \mathrm{pp}^{+}$solar cells with a thickness of $180 \mu \mathrm{m}^{12}$. For instance, Sheoran et al. $^{32}$ reported that the temperature of $115 \mu \mathrm{m}$ thick wafers was $70^{\circ} \mathrm{C}$ higher than that of $280 \mu \mathrm{m}$ thick ones, for the same belt furnace temperature. Do et al. ${ }^{25}$ and
Schiele et al. ${ }^{26}$, that developed $100 \mu \mathrm{m}$ thick devices, did not comment about the firing temperature used.

After the metal grid deposition, edge isolation was performed with laser radiation.

The devices were characterized under standard conditions $\left(100 \mathrm{~mW} / \mathrm{cm}^{2}\right.$, AM1.5G and $\left.25^{\circ} \mathrm{C}\right)$ in a class AAA solar simulator (CT150AAA, PET-Photoemission) calibrated with a silicon solar cell previously measured at CalLab - FhG-ISE (Fraunhofer-Institut für Solare Energiesysteme), Germany. Cells had an area of $61.58 \mathrm{~cm}^{2}$ (pseudo-square of $80 \mathrm{~mm} \mathrm{x}$ $80 \mathrm{~mm}$ ) with a standard two-busbars. Figure 2 shows the baseline structure and one thin solar cell produced. The solar cells with higher efficiency were characterized by measuring the spectral response and spectral reflectance (PV300 system, Bentham) in order to obtain the internal quantum efficiency (IQE). One $n^{+} n p^{+}$device was also analyzed by light beam induced current technique (LBIC) $)^{33}$. The solar cell was irradiated with laser radiation of four wavelengths $(648 \mathrm{~nm}$, $845 \mathrm{~nm}, 953 \mathrm{~nm}$ and $973 \mathrm{~nm}$ ) and the minority carrier diffusion length $\left(\mathrm{L}_{\mathrm{D}}\right)$ was estimated.

\section{Results and Analysis}

The doped regions presented an average sheet resistance of $\mathrm{R}_{\mathrm{SH}^{-} \text {Phosphorus }}=(58 \pm 5) \Omega /$ sq for phosphorus diffusion at

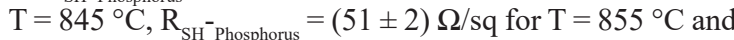
$\mathrm{R}_{\mathrm{SH}^{-}{ }_{\text {Boron }}}=(59 \pm 4) \Omega / \mathrm{sq}$, values suitable to the metal pastes based on $\mathrm{Ag}\left(\mathrm{n}^{+}\right.$face $)$and $\mathrm{Ag} / \mathrm{Al}\left(\mathrm{p}^{+}\right.$face $)$. Figure 3 shows the phosphorus and boron doping profiles. The surface phosphorus concentration is of around $1 \times 10^{21} \mathrm{~cm}^{-3}$ and the thickness of the $\mathrm{n}^{+}$region is in the range from $0.31 \mu \mathrm{m}$ to $0.40 \mu \mathrm{m}$,

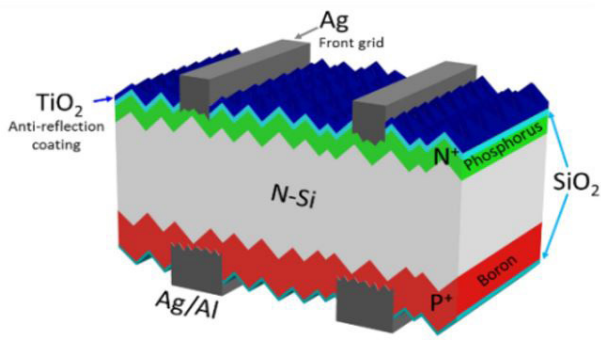

(a)

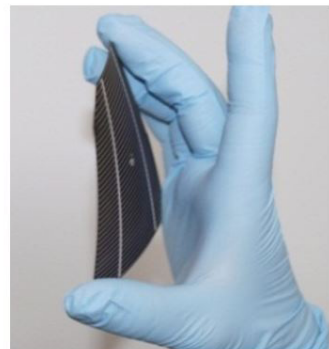

(b)

Figure 2. (a) Scheme of the solar cell with rear emitter and (b) thin device processed.

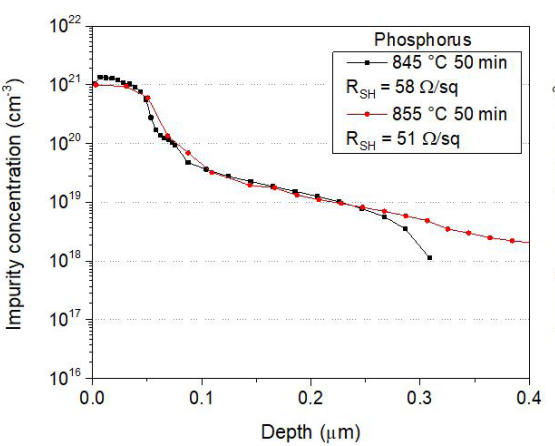

(a)

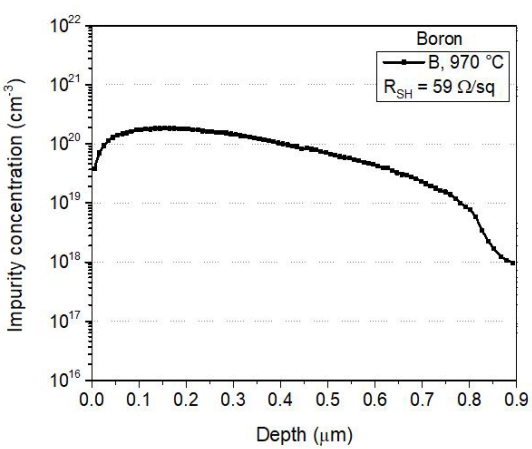

(b)

Figure 3. (a) Phosphorus and (b) boron impurity concentration obtained by ECV. 
as Figure 3a shows. The boron surface concentration is of around $4 \times 10^{19} \mathrm{~cm}^{-3}$ and the junction depth is of approximately $0.9 \mu \mathrm{m}$ (Figure $3 \mathrm{~b}$ ). The depletion of the B concentration close to the surface is due to the impurity segregation to the oxide layer grown during post-oxidation step after boron diffusion and during the phosphorus diffusion.

Table 1 presents the average electrical parameters of solar cells: open circuit voltage $\left(\mathrm{V}_{\mathrm{OC}}\right)$, short-circuit current density $\left(\mathrm{J}_{\mathrm{SC}}\right)$, fill factor (FF) and the efficiency $(\eta)$ of the devices. The average values were calculated from the results of at least five solar cells. The higher average efficiency was achieved in the range of firing temperature from $840{ }^{\circ} \mathrm{C}$ to $860{ }^{\circ} \mathrm{C}$. For the lower firing temperatures, the efficiency standard deviation is enhanced due to the less effective etch-through of the $\mathrm{TiO}_{2}+\mathrm{SiO}_{2}$ layer by $\mathrm{Ag}$ paste.

Table 2 summarizes the electrical characteristics of the devices with the highest efficiency for each firing temperature. The higher efficiencies were obtained at $830^{\circ} \mathrm{C}$ and $840{ }^{\circ} \mathrm{C}$. The latter was considered the best firing temperature taking into account the average values presented in Table 1. Moreover, the large efficiency deviation of $2 \%$ (absolute) observed when $\mathrm{T}_{\text {Firing }}=830^{\circ} \mathrm{C}$ shows that the firing of the $\mathrm{Ag}$ and $\mathrm{Ag} / \mathrm{Al}$ pastes in this temperature did not establish an ohmic contact with enough reproducibility.

Figure 4 shows the $\mathrm{J}-\mathrm{V}$ characteristics of the thin $\mathrm{n}^{+} \mathrm{np}^{+}$devices that reached the highest efficiency and one thick $\mathrm{n}^{+} \mathrm{pp}^{+}$device. The Ag and Ag/Al pastes of thin devices were fired at $840{ }^{\circ} \mathrm{C}$. The p-type $\mathrm{Cz}$ silicon wafers, boron doped, with similar resistivity of 1-20 $\Omega$.cm, were supplied by the same company that produced the n-type wafers. The results from thin solar cells presented in Figure 4 show that those cells reached higher $\mathrm{J}_{\mathrm{SC}}$ than thicker one, that we attributed to effective light trapping and a high bulk minority carrier diffusion length.

In the Figure 5, the internal quantum efficiency (IQE) of the devices with higher conversion efficiency $(\eta)$ is presented. The surface passivation applied to the solar cells were the same, a $\mathrm{SiO}_{2}$ thermally growth, but the thicker $\mathrm{n}^{+} \mathrm{pp}^{+}$one showed higher IQE for short wavelengths, as predicted by simulating the devices with the computer program $\mathrm{PC}-1 \mathrm{D}^{34}$ and setting the surface recombination velocity of $10^{5} \mathrm{~cm} / \mathrm{s}$ for the $\mathrm{n}^{+}$front surface. It is worth commenting that in the $\mathrm{n}^{+} \mathrm{np}^{+}$ structure the electron-holes generated by the solar radiation that is absorbed at the front surface need to be collected at the rear of the cell, where the pn junction is formed.

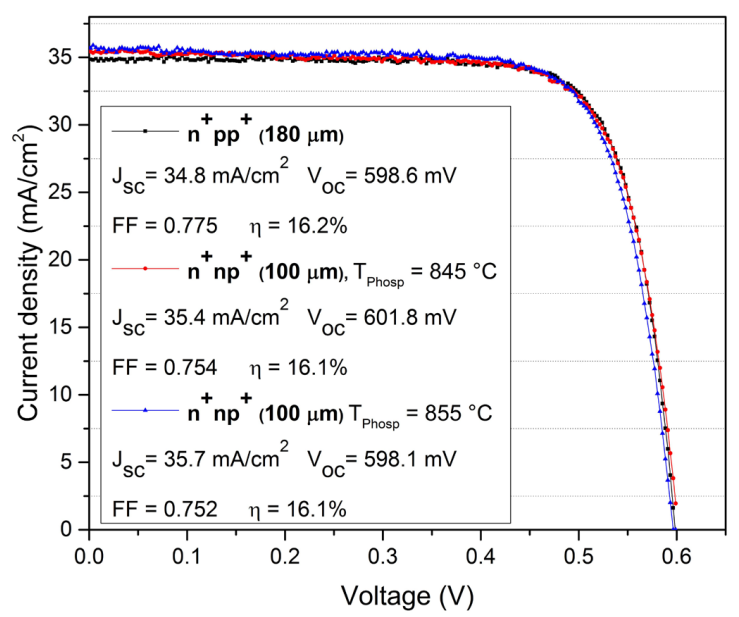

Figure 4. Current density as a function of the voltage of the $\mathrm{n}^{+} \mathrm{np}^{+}$ thin cells and $\mathrm{n}^{+} \mathrm{pp}^{+}$thick standard device. $\mathrm{T}_{\text {Phosp }}$ is the phosphorus diffusion temperature.

Table 1. Average open circuit voltage $\left(\mathrm{V}_{\mathrm{OC}}\right)$, short-circuit current density $\left(\mathrm{J}_{\mathrm{SC}}\right)$, fill factor $(\mathrm{FF})$ and efficiency $(\eta)$ of thin solar cells processed at different firing temperatures $\left(\mathrm{T}_{\text {Firing }}\right)$.

\begin{tabular}{ccccc}
\hline $\mathrm{T}_{\text {Firing }}\left({ }^{\circ} \mathrm{C}\right)$ & $\mathrm{V}_{\mathrm{OC}}(\mathrm{mV})$ & $\mathrm{J}_{\mathrm{SC}}\left(\mathrm{mA} / \mathrm{cm}^{2}\right)$ & $\mathrm{FF}$ & $\eta(\%)$ \\
\hline 820 & $595 \pm 5$ & $34.6 \pm 1.1$ & $0.71 \pm 0.05$ & $14.6 \pm 1.3$ \\
\hline 830 & $590 \pm 12$ & $34.1 \pm 1.6$ & $0.70 \pm 0.09$ & $14.2 \pm 2.0$ \\
\hline 840 & $594 \pm 5$ & $34.4 \pm 1.0$ & $0.73 \pm 0.02$ & $15.0 \pm 0.7$ \\
\hline 850 & $594 \pm 2$ & $34.7 \pm 0.2$ & $0.74 \pm 0.01$ & $15.2 \pm 0.3$ \\
\hline 860 & $590 \pm 1$ & $34.5 \pm 0.4$ & $0.74 \pm 0.01$ & $15.1 \pm 0.2$ \\
\hline 870 & $584 \pm 1$ & $34.5 \pm 0.4$ & $0.73 \pm 0.01$ & $14.7 \pm 0.2$ \\
\hline 880 & $577 \pm 5$ & $33.7 \pm 0.3$ & $0.70 \pm 0.02$ & $13.6 \pm 0.5$ \\
\hline 890 & $573 \pm 4$ & $33.5 \pm 0.2$ & $0.70 \pm 0.02$ & $13.4 \pm 0.3$ \\
\hline
\end{tabular}

Table 2. Electrical characteristics of the thin devices with the highest efficiency obtained at different firing temperatures $\left(T_{\text {Firing }}\right)$.

\begin{tabular}{ccccc}
\hline $\mathrm{T}_{\text {Firing }}\left({ }^{\circ} \mathrm{C}\right)$ & $\mathrm{V}_{\mathrm{OC}}(\mathrm{mV})$ & $\mathrm{J}_{\mathrm{SC}}\left(\mathrm{mA} / \mathrm{cm}^{2}\right)$ & $\mathrm{FF}$ & $\eta(\%)$ \\
\hline 820 & 600.5 & 35.7 & 0.74 & 15.8 \\
\hline 830 & 600.9 & 35.2 & 0.75 & 16.0 \\
\hline 840 & 601.8 & 35.4 & 0.75 & 16.1 \\
\hline 850 & 593.0 & 35.4 & 0.75 & 15.8 \\
\hline 860 & 591.6 & 34.8 & 0.75 & 15.3 \\
\hline 870 & 585.3 & 34.6 & 0.73 & 14.9 \\
\hline 880 & 576.7 & 34.0 & 0.71 & 14.0 \\
\hline 890 & 576.7 & 33.3 & 0.72 & 13.8 \\
\hline
\end{tabular}




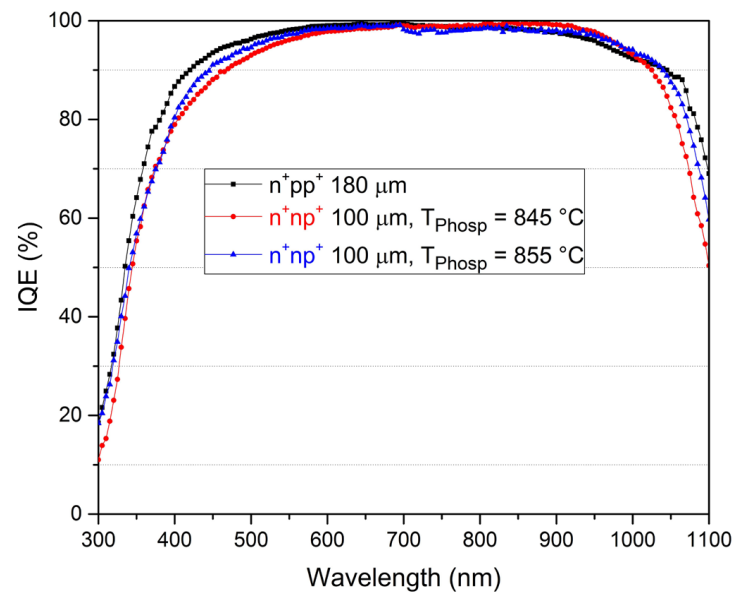

Figure 5. Internal quantum efficiency (IQE) of $n^{+} n p^{+}$thin solar cells with the highest efficiency and of the $\mathrm{n}^{+} \mathrm{pp}^{+}$thick standard device.

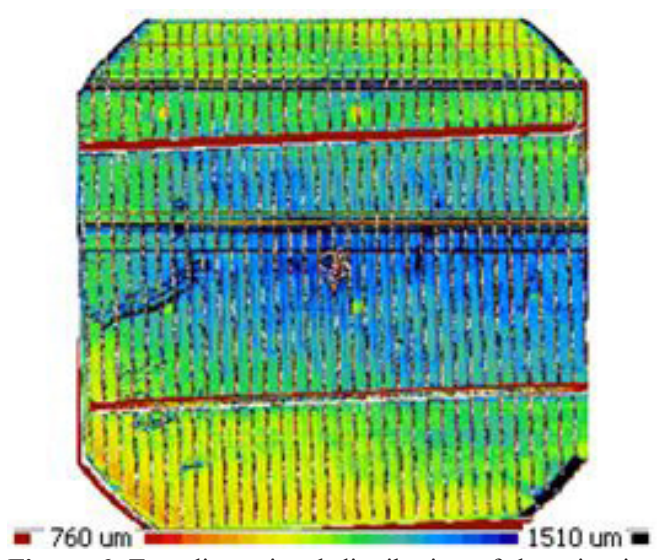

Figure 6. Two-dimensional distribution of the minority carrier diffusion length of the thin $\mathrm{n}^{+} \mathrm{np}^{+}$solar cell $\left(\mathrm{L}_{\text {DAverage }}=1200 \mu \mathrm{m}\right)$. Phosphorus diffusion was performed at $855^{\circ} \mathrm{C} ; \mathrm{T}_{\text {Firing }}=840^{\circ} \mathrm{C}$.

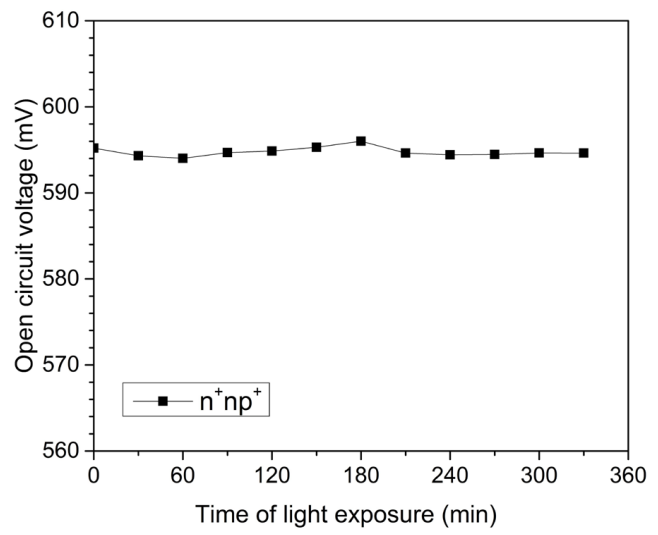

Figure 7. Open circuit voltage of a $\mathrm{n}^{+} \mathrm{np}^{+}$thin solar cell as a function of irradiation time. The device was exposed in a steady sun simulator, set to $1000 \mathrm{~W} / \mathrm{m}^{2}$ (AM $1.5 \mathrm{G}$ ).

In order to estimate the internal front reflectance $\left(\rho_{\mathrm{f}}\right)$ and the rear reflectance $\left(\rho_{\mathrm{r}}\right)$, the solar cells were simulated by using the PC1D program and these parameters were adjusted to fit in well the simulated IQE and hemispheric reflectance at longer wavelengths $(1000 \mathrm{~nm}-1100 \mathrm{~nm})$ to the experimental ones. The $\rho_{\mathrm{fi}}$ and $\rho_{\mathrm{r}}$ are the reflectance when the solar radiation impinges on the front and rear face, respectively, from inside the device. The solar cells have the front surface coated with $\mathrm{SiO}_{2} / \mathrm{TiO}_{2}$ film and the rear face coated by $\mathrm{SiO}_{2}$. The best fit between experimental and simulation results was found with $\rho_{\mathrm{fi}}$ and $\rho_{\mathrm{r}}$ equal to 0.95 . These values are similar to those presented in works that deal with light trapping in silicon wafers textured with random pyramid $^{35}$. Although the thickness of the device was reduced about $45 \%$, thinner solar cells presented an IQE (at $1100 \mathrm{~nm}$ ) approximately $10 \%$ lower than thick ones. Therefore, thin textured silicon wafers with the above mentioned films can produce efficient light trapping.

Figure 6 illustrates the distribution of the minority carrier diffusion length obtained by the LBIC technique of the thin $\mathrm{n}^{+} \mathrm{np}^{+}$device with $\mathrm{P}$ diffused at $855^{\circ} \mathrm{C}$ and $\mathrm{T}_{\text {Firing }}=840^{\circ} \mathrm{C}$. The average value of the diffusion length $\left(\mathrm{L}_{\text {DAverage }}\right)$ was of around $1200 \mu \mathrm{m}$, that is, twelve times the wafer thickness and corresponds to the high minority carrier lifetime of around $1.1 \mathrm{~ms}^{9,14}$.

Concerning the lower fill factor achieved by $\mathrm{n}^{+} \mathrm{np}^{+}$solar cells with $\mathrm{Ag} / \mathrm{Al}$ rear metal grid, this is an issue of n-type devices, as observed by Singha and Solanki ${ }^{14}$. To reduce the series resistance of the $\mathrm{Ag} / \mathrm{Al}$ metal grid, electroplating could be used to augment the finger thickness, but an additional process step would be not cost-effective.

The $\mathrm{n}^{+} \mathrm{np}^{+}$thin device, whose $\mathrm{J}-\mathrm{V}$ is presented in Figure 4 (P diffusion at $855^{\circ} \mathrm{C}$; $\mathrm{T}_{\text {Firing }}=840{ }^{\circ} \mathrm{C}$ ), was exposed in a sun simulator, set to $1000 \mathrm{~W} / \mathrm{m}^{2}$ (AM $1.5 \mathrm{G}$ ), during $330 \mathrm{~min}$ in order to evaluate the light induced degradation. After every $30 \mathrm{~min}$, solar cell was characterized by measuring the $\mathrm{J}-\mathrm{V}$ curve at standard conditions and no degradation was observed. Figure 7 presents the $\mathrm{V}_{\mathrm{OC}}$ measured during this period and small deviations from the initial value, less than $2 \mathrm{mV}$, were observed. As expected, n-type wafers did not present light induced degradation.

\section{Conclusions}

As observed by ITRPV 2018 report $^{2}$, efforts have to be made in the next years to use the crystalline silicon more efficiently and to improve the solar efficiency without significantly rising processing costs. Cost-effective silicon solar cells were fabricated by using $100 \mu \mathrm{m}$ thick wafers and efficiencies of around $16 \%$ were obtained. The firing thermal process of the $\mathrm{Ag}$ and $\mathrm{Ag} / \mathrm{Al}$ metal pastes were optimized and the higher efficiencies and the lower standard deviation of the average values were observed when the firing temperature was of $840{ }^{\circ} \mathrm{C}$. The thin $\mathrm{n}^{+} \mathrm{np}^{+}$solar cell was exposed to solar irradiation and no degradation was observed after $5.5 \mathrm{~h}$. Concerning the silicon amount to produce each watt, the developed thin $\mathrm{n}^{+} \mathrm{np}^{+}$device can achieve the value of $1.6 \mathrm{~g} / \mathrm{W}$, about $40 \%$ lower than the obtained in standard $\mathrm{n}^{+} \mathrm{pp}^{+}$thick solar cells processed with the same fabrication sequence.

\section{Acknowledgments}

The authors acknowledge the financial support provided by the Brazilian financing agencies CNPq and CAPES. 


\section{References}

1. Liu J, Yao Y, Xiao S, Gu X. Review of status developments of high-efficiency crystalline silicon solar cells. J Phys D Appl Phys. 2018;51:1-12.

2. ITRPV: International Technology Roadmap for Photovoltaic [Internet]. 2018 Results 10th ed. Germany: ITRPV; 2019 [cited 2020 Jan 29]. Available from: http://itrpv.vdma.org

3. Mann SA, Wild-Scholten MJ, Fthenakis VM, Van Sark WGJHM, Sinke WC. The energy payback time of advanced crystalline silicon PV modules in 2020: a prospective study. Prog Photovolt Res Appl. 2014;22:1180-94.

4. Lim JR, Kim S, Ahn HK, Song HE, Kang GH. Analysis of the bowing phenomenon for thin c-Si solar cells using partially processed c-Si solar cells. Energies. 2019;12:1593.

5. Glunza SW, Rein S, Warta W, Knobloch J, Wettling W. On the degradation of Cz-silicon solar cells. In: Proceedings of the 2nd World Conference on Photovoltaic Solar Energy Conversion Viena; 1998 July 6-10; Vienna, Austria. Proceedings. Piscataway, New Jersey: IEEE; 1998. p. 1343-1346.

6. Glunz SW, Rein S, Lee JY, Warta W. Minority carrier lifetime degradation in boron-doped Czochralski silicon. J Appl Phys. 2001;90(5):2397-404.

7. Lindroos J, Savin H. Review of light-induced degradation in crystalline silicon solar cells. Sol Energy Mater Sol Cells. 2016;147:115-26.

8. Hallam B, Herguth A, Hamer P, Nampalli P, Wilking S, Abbott $\mathrm{M}$, et al. Eliminating light-induced degradation in commercial p-type czochralski silicon solar cells. Appl Sci. 2017;8(10):1-19.

9. Cotter JE, Guo JH, Cousins PJ, Abbot MD, Chen FW, Fisher $\mathrm{KC}$. p-type versus n-type silicon wafers: prospects for highefficiency commercial silicon solar cells. IEEE Trans Electron Dev. 2006;55(8):1893-901.

10. MacDonald D. The emergence of n-type silicon for solar cell manufacture. In: 50th Annual AuSES Conference (Solar); 2012; Melbourne Australia. Proceedings. Australia: Australian Solar Council; 2012. p. 1-6.

11. Song D, Xiong J, Hu Z, Li G, Wang H, An, H, et al. Progress in n-type Si solar cell and module technology for high efficiency and low cost. In: 38th IEEE Photovoltaic Specialists Conference; 2012 June 3-8; Austin, Texas. Proceedings. Piscataway: IEEE; 2012. p. 3004-3008.

12. Rehman A, Lee SH. Advancements in n-type base crystalline silicon solar cells and their emergence in the photovoltaic industry. The Scientific World Journal, 2013;2013:1-13.

13. Bordihn S, Mertens V, Cieslak J, Zimmermann G, Lantzsch $\mathrm{R}$, Scharf J, et al. Status of industrial back junction n-type $\mathrm{Si}$ solar cell development. Energy Procedia. 2016;92:678-83.

14. Singha B, Solanki CS. N-type solar cells: Advantages, issues, and current scenarios. Mater Res Express. 2017;4(7):1-9.

15. Kessler M, Ohrdes T, Wolpensinger B, Harder NP. Charge carrier lifetime degradation in $\mathrm{Cz}$ silicon through the formation of a boron-rich layer during $\mathrm{BBr}_{3}$ diffusion processes. Semicond Sci Technol. 2010;25:1-9.

16. Masuko K, Shigematsu M, Hashiguchi T, Fujishima D, Kai $\mathrm{M}$, Yoshimura N. Achievement of more than $25 \%$ conversion efficiency with crystalline silicon heterojunction solar cell. IEEE Journal of Photovoltaics. 2014;4(6):1433-5.

17. Sheng J, Wang W, Yuan S, Cai W, Sheng Y, Chen Y, et al. Development of a large area n-type PERT cell with high efficiency of $22 \%$ using industrially feasible technology. Sol Energy Mater Sol Cells. 2016;152:59-64.

18. Lu G, Zheng F, Wang J, Shen W. Thin $\mathrm{Al}_{2} \mathrm{O}_{3}$ passivated boron emitter of n-type bifacial c-Si solar cells with industrial process. Prog Photovolt Res Appl. 2017;25:280-90.

19. Rothhardt P, Demberger C, Wolf A, Biro D. Co-diffusion from APCVD BSG and $\mathrm{POCl}_{3}$ for industrial n-type solar cells. Energy Procedia. 2013;38:305-11.
20. Wehmeier N, Nowack A, Dorn S, Kiefer F, Brendemühl T, Kajari-Schröder S. Optimization and application of a single-stage co-diffusion process for industrial n-type silicon solar cells. In: 33rd European Photovoltaic Solar Energy Conference and Exhibition; 2017 Sep 25-27; Amsterdan, The Netherlands. Proceedings. Pittsfield, MA: Photovoltaic Media; p. 589-94.

21. Yadav A, Singh G, Nekovei R, Jeyakumar R. c-Si solar cells formed from spin-on phosphoric acid and boric acid. Renew Energy. 2015;80:80-4.

22. Das A, Kyungsun R, Rohatgi A. $20 \%$ efficient screen-printed n-type solar cells using a spin-on source and thermal oxide/ silicon nitride passivation. IEEE Journal of Photovoltaics. 2011;1(2):146-52.

23. Ryu K, Cho E, Rohatgi A, Ok Y. Process development and comparison of various boron emitter technologies for highefficiency ( $21 \%$ ) n-type silicon solar cells. Prog Photovolt Res Appl. 2016;24(8):1109-15.

24. Augusto A, Looney E, Cañizo C, Bowden SG, Buonassisi T. Thin silicon solar cells: pathway to cost-effective and defect tolerant cell design. Energy Procedia. 2017;124:706-11.

25. Do KS, Baek T, Kang MG, Choi SJ, Kang GH, Yu GJ, et al. Experimental and simulation study for ultrathin $(\sim 100 \mu \mathrm{m})$ mono crystalline silicon solar cell with $156 \times 156 \mathrm{~mm}^{2}$ area. Met Mater Int. 2014;20(3):545-50.

26. Schiele Y, Book F, Seren S, Hahn G, Terheiden B. Screenprinted Al-alloyed rear junction solar cell concept applied to very thin $(100 \mu \mathrm{m})$ large-area n-type si wafers. Energy Procedia. 2012;27:460-6.

27. Zanesco I, Moehlecke A. Impurity diffusion process in silicon wafers to fabricate solar cells (Processo de difusão de dopantes em lâminas de silício para a fabricação de células solares). Brazilian patent PI12030606, BR 102012030606 9. 2012 Nov 30.

28. Crestani T, Zanesco I, Moehlecke A, Ly M. Analysis of the boron concentration profile to produce p-type silicon solar cells by reducing thermal steps. In: Actas de la XLI Reunión de Trabajo de la Asociación Argentina de Energías Renovables y Medio Ambiente; 2019 Nov 11-15; Cordoba. Argentina: Facultad de Ingeniería de la Universidad Nacional de Jujuy; 2018.

29. Osório VA, Moehlecke A, Zanesco I. Influence of the order of boron and phosphorus diffusion on the fabrication of thin bifacial silicon solar cells. Mater Res Express. 2016;3(10):105022.

30. Peiner E, Schlachetzki A, Kruger D. Doping profile analysis in Si by electrochemical capacitance-voltage measurements. J Electrochem Soc. 1995;142:576-80.

31. Zanesco I, Razera RAZ, Moehlecke, A. Analysis of the SiO2 passivation of the rear and front surface of solar cells with selective back surface field. Materia. 2017; 22(Suppl. 1):1-9.

32. Sheoran M, Upadhyaya V, Upadhyaya A, Rohatgi A. Highefficiency screen-printed thin silicon solar cells. In: Proceedings of the 22nd European Photovoltaic Energy Conference; 2007 Sep 3-7; Milan, Italy. München, Germany: EU PVSEC. p. 1738-41.

33. Semilab [homepage on the Internet] WT-2000PV User Manual. Measurement tool for solar cell manufacturing. Budapest, Hungary: Semilab; YEAR. [cited 2020 Jan 29] Available from: http://www.semilab.com.

34. Basore PA, Clugston DA. PC1D Version 5: 32-bit solar cell modeling on personal computers. In: Conference Record of the 26th IEEE Photovoltaic Specialists Conference; 1995 Sept. 29-Oct. 3. Anaheim, USA. São Paulo: IEEE; 1995. p. 207-210.

35. Tobías I, Rodriguez JM, Luque A. Experimental extraction of light confinement parameters for textured silicon wafers. Prog Photovolt Res Appl. 1995;3:177-87. 